\title{
Hvad er elementær moral i dag?
}

\author{
Af William Michelsen
}

Vartovbogen 1994, red af Anna Bojsen-Mфller, Jørgen Kristensen og E. Jakob Petersen. Kirkeligt Samfunds forlag, Kфbenhavn. 160 sider. 90 kr.

Den forandring, der sås $\mathrm{i}$ forrige årgang, holder stadig stik. Bogen er ikke længere fortrinsvis af opbyggelig karakter, men i stedet oplysende. Af de 10 forfattere er de 5 ganske vist teologer, men kun et par af deres artikler - en om kong David og en om det evige liv - er af opbyggelig karakter. De fleste af artiklerne har historisk eller litterært indhold. Bogen indledes med en betragtning over »Velfærdsstat og etik«, som jeg skal komme tilbage til, og afsluttes med en videnskabelig betragtning af myterne om folkenes oprindelse i folkevandringstidens Europa, begge skrevet af universitetslærere. - Grundtvig var og betragtede sig selv som en historiker, der var blevet teolog. Bogen er forsåvidt i overensstemmelse med Kirkeligt Samfunds udgangspunkt: Grundtvigs kirkelige og folkelige tanker.

Den spænder vidt: fra en gennemgang af en række romaner af Knut Hamsun til nogle grundtvigsk inspirerede højskoler i Bangladesh. Den eneste bog om Grundtvig, de derude fik tilsendt, var af Kaj Thaning. Af ham står der også en artikel i bogen her. Den er fra 1937 og drejer sig om den teologiske situation dengang; men redaktionen hævder, at den fortsat har aktualitet. Titelen er: »Menighed og folk«. Jeg citerer:

»Vi er tidens børn, og tiden, historien, former sine børn. Vi kan søge at forskanse os mod dens tale - også kirkeligt - men sandheden kræver ærlighed og saglighed af os. Kirkelighed betyder forskansning, men Guds tale i historien vil sprænge vor lukkede verden, - hvad enten den er kirkelig eller af anden art - og åbne for os folkets verden, Guds verden.«

Redaktionen har ret. »Det, som evangeliet er, er det kun i folket.« - det var Thanings tesis dengang. Hans forklaring kommer straks efter:

»Tror folket ikke, tror menigheden dog for folket. Tror folket, så er menigheden intet. Målet er ikke, at folket indlemmes i menigheden, men at menigheden går under, bliver til ingenting, når den har bragt evangeliet til folket, og folket har taget derimod.«

Det er klare ord. Det er den slags, vi savner fra kristen side i dag.

Vil man have en sympatisk skildring af grundtvigianismens fortid, skal man læse Kim Sakker Esmarks skildring af Holger Begtrup som historiefortæller. Og man kan få et nutidigt eksempel i Eva Meiles artikel »David«. Men vil man se, hvor nutidig, grænsesprængende Grundtvig selv stadig er, så læs Klavs Birkholms gennemgang af Grundtvigs sene digt »Jord og Himmel at forbinde«, der kunne høres i radioens 
program 1 søndag morgen den 29. august 1993. Her har vi den på tryk. Man kan altså i Vartovbogen stadig møde Grundtvig i dag.

Den mest spændende artikel er alligevel Erik Skyum-Nielsens kyndige kritik af det officielle Tillæg til Den danske Salmebog. Her har Informations udmærkede kritiker af dansk lyrik stillet sig den opgave at definere, hvad en salme er. Det falder altså ikke ham ind at påstå, at Grundtvigs Sang-Værk skal vurderes på samme måde som Aarestrups samtidige digte. Han henviser i den henseende til en artikel af Peter Thyssen i tidsskriftet Fønix om »Teologiens vilje til kunst « (nr. 4, 1993). Men Skyum-Nielsens artikel bør under alle omstændigheder læses af enhver, der har noget som helst at sige om indholdet af en ny salmebog.

Søren Kierkegaard har skrevet en bog med titelen »Frygt og Bæven«, der med udgangspunkt i Abrahams situation stiller det spørgsmål: »Gives der en teleologisk suspension af det etiske?« Skyum-Nielsen stiller i denne artikel tre andre spørgsmål:

1. »hvorvidt der mon gives en teologisk suspension af det æstetiske«,

2. »hvorvidt der gives en astetisk suspension af det teologiske«, og

3. »hvorvidt der gives en pragmatisk suspension af det teologiske såvel som af det æstetiske, sådan som redaktionen bag tillægget åbenbart forestiller sig, når de lægger op til, at de 160 tekster nu skal prøves af i praksis, som om der ikke fandtes kriterier for, hvad en salme er.«

Skyum-Nielsen véd meget godt, at fortalerne for de moderne salmer har "publikummet på deres side - de mennesker, som kirken af $\mathrm{i}$ dag ikke kan tillade sig at skræmme bort med gamle, halvt uforståelige vers.« Skyum-Nielsen svarer:

»Hermed går kirken ind $\mathrm{i}$ et stadig mere skingert kaos af højtråbende formidlingstiltag og døver folks fornemmelse for, at kirken til syvende og sidst skal være det anderledes sted, det sted, hvor der tales og synges på en måde, som vi ellers ikke har mulighed for at høre, opleve, være med til. I dette fællesskab ... er det salmesangen skal indgå.«

En salme skal ifølge Skyum-Nielsen have: »a) poetisk kvalitet, b) teologisk lødighed og c) empirisk slidstyrke.« Om sidste punkt skriver han, »at versene skal have en overbevisende kvalitet i sig selv, og at de, i kraft af bl.a. denne, skal kunne holde til at blive sunget af mange forskellige mennesker ved mange forskellige gudstjenester og kirkelige handlinger.« Hvilket han derefter gennemgår med klare og belysende eksempler og begrundet kritik, bl.a. af store lyrikere. Det er ikke meget, der finder nåde for hans øjne. Til sidst skriver han:

»Det skal understreges, at der i det nye salmebogstillæg bestemt står udmærkede ting, f.eks. bibelhistoriske salmer af Johannes Møllehave, enkelte kraftige vers af især Aastrup. Men til en ny dansk kirkekunst er der endnu langt, og det er derfor ærgerligt, at hvad der i sit indhold ligner et kirkeministerielt debatudspil, har fået så officiøs en form, at man i redaktionen af en kommende salmebog må gøre adskillig modstand, hvis ellers man vil undgå at stå med bundne hænder.« 
Han slutter med endnu et citat af Peter Thyssen og følgende lille vers »fra en dansk salmedigters opslagstavle«:

»Du, som gav mig denne trang,

tænk dig om en anden gang!«

Hvilket jeg vil fortolke således: det er ikke altid en guddommelig inspiration, der står bagved ethvert salmeforsøg - det være sig nok så velment.

Man kan måske trøste sig efter denne gavnlige kritik af vor tids salmedigtning ved at ty til Jens Lysters beskrivelse af en af vore ældste salmedigtere, der i begyndelsen af forrige århundrede var helt glemt, men blev genopdaget, nemlig Hans Christensen Sthen, hvis liv var mere bevæget, end vi hidtil har forestillet os.

Men hvis man tyr til den indledende artikel om velfærdsstat og etik for at få svar på de moralske problemer, der kan sammenfattes under ordene skattesnyd og sort arbejde, men her kaldes »fifleri«, vil man efter mit skøn blive skuffet. Dér gives der ganske vist en række klare og delvis velkendte eksempler fra det daglige liv, efterfulgt af et klart statistisk ræsonnement, der konkluderes deri, at vi er fanget $\mathrm{i}$ »de store tals dilemma«. Problemet er forsåvidt klart stillet. Men det er ikke besvaret. Hvordan skal vi selv forholde os i disse situationer? - Svaret kan ikke gives ved det ræsonnement, artikelen beskriver, og som konkluderes i den sætning: »At elske sin næste er svært $\mathrm{i}$ en verden underkastet de store tals dilemma."

Forfatteren, Jørn Henrik Petersen, Odense, der er professor dr. phil. og licentiat i økonomi, henviser yderligere til »den kendte velfærdsstatstilhænger Bent Rold Andersens formulering af problemet«. Han har i »en glimrende analyse af velfærdsstatens rationalitet og irrationalitet ... været inde på, at man ved den brede dækning, som i princippet omfatter alle befolkningsgrupper, og finansiering over den generelle beskatning har fjernet de bånd mellem ydelse og nydelse, der kan erindre os alle om, at velfærdsstaten ikke deler egenskab med hin gris Særimner, der aldrig kunne spises op.« Selv sammenfatter professor Jørn Henrik Petersen problemet således:

»Der er stor psykologisk forskel på at modtage økonomisk, praktisk og følelsesmæssig støtte fra en ægtefælle, et familiemedlem, en ven eller en nabo og at modtage ydelser fra en anonym, offentlig institution.«

Kortere og klarere kan det næppe siges. Det er vor situation.

Men det er ikke et svar på det etiske eller moralske spørgsmål: hvad skal vi gøre? - Som enkeltmennesker og som samfund. Et rent videnskabeligt rasonnement kan ikke give det etiske svar.

Mon ikke det var det, vi skulle have lært af, at Adam blev advaret mod at spise af træet til kundskab om godt og ondt - ikke af »Kundskabstræet « slet og ret, som man plejer at sige. Nej! - Han blev netop advaret mod at spise af det træ, hvis frugt gav viden om, hvad der er godt, og hvad der er ondt. Vi har ment, at vi deraf ville lære at gøre det gode og lade være at gøre det onde. Paulus vidste bedre: »Det gode, som jeg vil, det gør jeg ikke, men det onde, som jeg ikke vil, det gør jeg.« (Rom. 7.19) Velfærdsstaten er en frugt af den politisk- $\emptyset$ konomiske tænkning, man har sat $i$ kristendommens sted. 
Vi behøver ikke blot det kristne evangelium. Vi behøver den lov, dvs. dén almengyldige, almenmenneskelige moral, uden hvilken evangeliet om syndernes forladelse bliver meningsløst. Den juridiske lovgivning kan ikke træde i stedet for en almenmenneskelig moral. For atter at citere Paulus, der var fortrolig med den jødiske lov, som gik ud fra de ti bud, der var skrevet af Gud på de to stentavler, Moses fik med fra bjerget Sinai:

»...det er ikke dem, som hører loven, der er retfærdige for Gud, men de, som gør loven, vil blive gjort retfærdige. For når hedningerne, der ikke har loven, af naturen gør, hvad loven siger, så er de, uden at have en lov, deres egen lov. De viser, at de har den gerning, som loven kræver, skrevet i deres hjerte, og deres samvittighed optræder som vidne, og deres tanker anklager eller forsvarer hinanden - på den dag, da Gud dømmer det, som skjuler sig i mennesker, efter mit evangelium ved Kristus Jesus.« (Rom. 2,13-16.)

Der findes altså efter kristen opfattelse, også hos os ikke-jøder, en almengyldig, almenmenneskelig lov, som er forudsætningen for Jesu evangelium, og som også er forudsætningen for ethvert menneskeligt samfund.

Det er denne almengyldige, almenmenneskelige moral, vi har glemt, da vi troede, at vi kunne sætte videnskaben i religionens sted. Det er denne situation, vi opdager nu, og som Vartovbogen 1994 indirekte gør os opmærksomme på. 